\title{
Socio Economic Status of aged population residing in Shimla Hills of North India
}

\author{
Rekha Suman ${ }^{1}$, S. K. Sharma ${ }^{1}$, Anil Gupta ${ }^{2}$
}

\author{
${ }^{1}$ Department of Sociology, Himachal Pradesh University, Summer hill, Shimla, Himachal Pradesh, India \\ ${ }^{2}$ Department of Food Science and Technology, Dr YS Parmar University of Horticulture and Forestry, Nauni, Solan Himachal Pradesh, \\ India
}

\begin{abstract}
Socio-economic status is the foremost issue in the contemporary world, especially in the developing world. The socio-economic status in the rural areas is gradually improving over a period of time. The present study approaches the senior citizens (aged population) economic status of rural and urban areas of Shimla-the state capital of Himachal Pradesh. The study focuses on economic conditions like source of income, occupation, impact of literacy on income source. During this study, an attempt has been made to find out the actual socioeconomic status of population of different income groups. A sample size of 150 was selected for conducting this study in rural as well as urban elderly population and the study is based on door to door data collection with the help of a suitable questionnaire. The collected data have been classified into four income groups and simple percentage method is followed to analyse the data. The results shows that in rural area $99.32 \%$ aged covered under monthly income between Rs 2000 to Rs 6000 as compared to only 34.55\% urban in the income group. In urban area, non-significant difference in the income was noticed with a maximum $37.99 \%$ in a range of Rs 6000 to Rs 15000. Thus, only a few percentages of people in old ages have sufficient sources of income and can enjoy little better life rural areas.
\end{abstract}

Keywords-Socio-economic status, income, educational level, occupation.

\section{INTRODUCTION}

The world's population is ageing and virtually all countries are experiencing growth in the number as well as proportion of older persons in their populations. Globally, the number of older persons is growing faster than the numbers of people in other age groups (World population ageing 2015). Aging of population in India is apparent from the trend depicted over different censuses since 1951. The recent census puts up the count of older adults to 103,849,040 (Census of India, 2011). This figure amounts to $8.6 \%$ of the population of India in 2011. Like other Indian states, Himachal Pradesh-a hilly state of North India is witnessing a progressive increase in proportion of aged people from $8 \%$ in 2001 to $10.2 \%$ in 2011(MOSPI 2012, WHO 2017)). Elderly or old age consists of ages nearing or surpassing the average life span of human beings. According to National Policy on Older Persons (1999), elderly is a person who is of age 60-years and over and the United Nations also consider the same age for reference of older population (Census 2011). Further, the United Nations Population Division report, predicted that the India's older population will increase dramatically over the next four decades, constituting $19 \%$ of total population of India by 2050 (UNPD 2011).
Population ageing is a global phenomenonand there are different factors that influence the aspect of the course of life such as; physiological, social, psychological, economic, environmental and cultural, it may also affect the quality of life (Celichet al. 2010). The elder persons in the society face anumber of problems due to absence of assured and sufficient income to support themselvesfor healthcare, social securities with quality of life. The quality of life has been conceptualizedin so many approaches, being the subject ofconsiderable research in the health field. It is definedas the "individual's perception of their position inlife in the context of culture and value systemsin which they live and in relation to their goals, expectations, standards and concerns" (WHO 1995).

The current situation of the society in developing nations is rapidly moving from poor economy to developed economy with the development of social conditions. The rural areas are very less developed as compared to urban areas in terms of social, cultural and economic aspects. The socio-economic characteristics are the important tools to the measures of human development. It is a measure of an individual, family or a group of peoples, economic and social position on the basis of education, income, health and occupation (Mustaquim and Islam 2014). Socio-economic is the most 
important determinant of the livelihoods as it influences levels of knowledge, skill and income conditions which mean for their living. According to Rathod and Ningshen (2012), Socio-economic status is an economic and sociological combined total measure of a person's work experience. Krieger et al. (1997) defines the socioeconomic position as 'an aggregate concept that includes both resource-based and prestigebased measures of social class position. Socio-economic status is often considered a personal demographic variable. However, it can also reflect aspects of an individual's broader environment and thus can be measured at the individual level or the area level (Lynch and Kaplan 2000; Bollen et. al. 2001)

During the past decade, there are numerous studies highlighting the morbidity pattern in different geographical areas of India, but none relating to this hilly state of North India. The elderly living in hilly terrain may have different perceived needs and socio-economic pattern. The present study is comparative in nature focusing on the life of elderly people in the rural and urban areas. The primary focus is to analyze how for the above held theoretical assumptions or the hypotheses raised above stand in the empirical reality. This study follows exploratory and descriptive research design. The use of such a research design is highly appropriate in studies like the present one. The present study on the emerging problem of ageing conducted in the context of Himachal Pradesh, which constitutes a peculiar socio-cultural setting, is a beginning, as to the best knowledge of the researcher there does not exist any such study on the elderly in district Shimla. It is in the light of the empirically observed facts that it would describe and explain the problem of ageing in the hilly areas. The results of this study are expected to make a broad conclusion on the status of elderly residing in the rural area of Himachal Pradesh.

\section{MATERIALS AND METHODS}

The present study is conducted in rural and urban areas of district Shimla, Himachal Pradesh, a hill state located in the north-west Himalayas. The total population of the elderly in Himachal Pradesh is 7, 03,000constituting 10.2 per cent of the total population of the state (MOSPI, 2016). The sex-wise distribution of the elderly is 51.5 per cent female 48.5 per cent male. The population of the female elderly is more than that of male elderly in all the districts of Himachal Pradesh. In view of the fact that district Shimla has sizeable population ofthe elderly and it also being the state capital district, the study was conducted in Shimla district. The total population of the elderly in Shimla district is 42,874 which constitute 0.82 per cent of the State's total population. The district is spread over 17 development blocks tehsils and sub-tehsils. It is difficult to cover all the areas as most of these do not qualify in terms of the need of the study. Therefore, the study is restricted to Shimla urban and rural having approximately 20,437 and 13,393 families respectively. To limit the size of sample, alternative zone was randomly selected. The city of Shimla being the only class I urban area ofthe district as well as the state, it became the rational choice. Within the city Sanjauli area was further selected for the purpose of field work. In order to select a rural setting, village Shilagaon in the Kotkhai Tehsil was selected. The field work was carried out in villages, namely Bakhol, Jahru, Koti, Chakuna, Kadai, Majholi, Bangra, Khuli, Pajauri, Gumma, Anu, Dotchi, and Dhanguli.

Study target area: The possible number of the elderly was identified on the basis of the voters' lists which carried village-wise information on the male and females with their age. In this way a sample of 300 elderly was chosen for the study by giving 50 per cent representation to rural and urban areas. The random sampling procedure was used to contact the elderly population. The number of families is calculated by assuming an average number of 5 members in a family.

Techniques of data collection: The data for the present study was collected by carrying out field work. In the selected development blocks and villages within these blocks. The data were collected through primary sources. The data was collected with an Interview Scheduled designed keeping in view the hypotheses and objectives of the study. Since structural variations i.e. the social and economic status of the elderly is found to be crucial in determining their life style and life chances.

Data analysis: The data collected was coded and all the qualitative information was transformed into quantitative data. The entire data were processed in accordance with the need of each objective of the study. The cross tabulation of data was carried out by classifying the respondents into ruralurban categories.

\section{RESULTS AND DISCUSSIONS}

The old age is the last phase of the human life cycle and its timing, impact on relationship and the meaning attached to it vary in different societies and even in different subgroups of a society. In the process of ageing, the last phase is considered as bodily decline of human being and ultimately terminating into death. In this phase majority of the aged, besides health problems also face social, psychological, biological and economic problems. The 
problems faced of course are not uniform in their nature and vary from individual to individual.The aged are classified into three different categories namely active, passive and dependent ageing. This categorization is based on age after 59 years. Each of the above mentioned three categories of the senior citizens spans 60-70 years, 71-80 years and 81 years and above respectively.

\section{Distribution of respondents on basis of age group}

The senior citizens contacted for the study, (Table 1) indicate more than two-third of them (71.66 per cent) falls in the active ageing category (60 to 70 years) and the respondents decreased to less than one-fifth in the second category called passive ageing ( 71 to 80 years). Further, in the third group i.e. the dependent category of ageing population, the number of the respondents is the smallest.
The gradual decline in the number of the ageing people in the sample is due to the fact that with the increase in the age mortality rate increases and therefore smaller percentage is found among the dependent aged group. The comparative analysis makes the rural-urban differences quite conspicuous. The number of respondents in this category in rural areas is more as compared to urban areas. A number of factors seem to be responsible for the above mentioned trend. Firstly, better health facility in the urban areas contributes to low mortality rate. Secondly, illiteracy takes its toll in the rural areas by making people less health conscious as compared to their urban counterparts. Due to these factors, the data indicate that in the hill state of Himachal Pradesh, the urban based senior citizens seem to live longer than their brothers in the rural areas.

Table 1. Age of the senior citizens in rural and urban areas

\begin{tabular}{|l|c|c|c|c|c|c|}
\hline \multicolumn{1}{|c|}{ Age } & Rural & Percentage & Urban & Percentage & Total & Percentage \\
\hline 60 & 21 & 14.00 & 43 & 28.66 & 64 & 21.33 \\
\hline $61-65$ & 47 & 31.33 & 41 & 27.33 & 88 & 29.33 \\
\hline $66-70$ & 33 & 22.00 & 30 & 20.00 & 63 & 21.00 \\
\hline $71-75$ & 20 & 13.33 & 12 & 8.00 & 32 & 10.66 \\
\hline $76-80$ & 19 & 12.66 & 8 & 5.33 & 27 & 9.00 \\
\hline $81-85$ & 7 & 4.66 & 11 & 7.33 & 18 & 6.00 \\
\hline $86+$ & 3 & 2.00 & 5 & 3.33 & 8 & 2.66 \\
\hline Total & 150 & & 150 & & 300 & \\
\hline
\end{tabular}

\section{Sex-wise distribution of respondents}

The sample size was selected randomly and during the process of data collection a considerable number of female senior citizens from both rural as well as urban areas were included. However, the males in rural as well as urban areas (Table 2) constitute the maximum number (57.66 per cent) with 42.33 per cent females. Unlike the distribution of male and female population in the Indian society in general and Himachal Pradesh in particular the number of males is relatively higher. The rural-urban distribution of data also follows the similar trend as has been witnessed in the case of total sample with a variable ratio. The number of males is more in urban as well as rural areas than that of the females. However, it may be argued that besides the chance factor, the values of patriarchy whereby male domination prevents women's representation, the number of female remains relatively smaller from that of the males.

Table 2. Sex-wise distribution of elderly in urban and rural areas

\begin{tabular}{|l|c|c|c|c|c|c|}
\hline \multicolumn{1}{|c|}{ Sex } & Rural & Percentage & Urban & Percentage & Total & Percentage \\
\hline Male & 82 & 54.66 & 91 & 60.66 & 173 & 57.66 \\
\hline Female & 68 & 45.33 & 59 & 39.33 & 127 & 42.33 \\
\hline Total & 150 & & 150 & & 300 & \\
\hline
\end{tabular}

\section{Distribution of respondents on basis of education}

The educational profile of the aged and their spouses indicates that large number 45.69 percent male and 32.88 percent females were illiterate and a very small proportion of them are in the functional literate category(Table 3). Among the remaining a considerable number of them are in matriculation and primary level of education. In the graduation category there are only 9.93 and 3.36 per cent respectively. The majority of the spouses are concentrated in the matriculate and the middle standard education category. The remaining has higher education including post-graduates and professional degrees but distributed in small proportions. A large number of females in rural as well as urban area refused to disclose their educational 
profile. The rural urban comparison indicates that majority of the respondents and their spouses residing in the rural areas fall in the illiterate categories. The number of illiterate in urban areas is relatively very small. It is also observed that while the rural based respondents and their spouses are mainly concentrated in the lower educational categories, the number of urban elderly and their spouses is found to be more in the higher educational categories. One of the reasons accounting for this gap is the lack of educational opportunities in the past for the rural people in general.

Table 3. Education wise distributionof elderly in urban and rural areas

\begin{tabular}{|c|c|c|c|c|c|c|c|c|c|c|}
\hline \multirow[t]{2}{*}{ Education } & \multicolumn{4}{|c|}{ Rural } & \multicolumn{4}{|c|}{ Urban } & \multirow{2}{*}{$\begin{array}{l}\text { Total } \\
\text { self }\end{array}$} & \multirow{2}{*}{$\begin{array}{l}\text { Total } \\
\text { spouse }\end{array}$} \\
\hline & Self & \%age & Spouse & \%age & Self & \%age & Spouse & \%age & & \\
\hline Illiterate & 56 & 72.70 & 41 & 56.20 & 13 & 17.56 & 8 & 10.53 & $\begin{array}{c}69 \\
(45.69)\end{array}$ & $\begin{array}{c}49 \\
(32.88)\end{array}$ \\
\hline Primary & 13 & 16.90 & 5 & 6.84 & 7 & 9.46 & 7 & 9.21 & $\begin{array}{c}20 \\
(13.24)\end{array}$ & $\begin{array}{c}12 \\
(8.05)\end{array}$ \\
\hline Middle & 2 & 2.60 & 2 & 2.73 & 7 & 9.46 & 8 & 10.53 & $\begin{array}{c}9 \\
(5.96)\end{array}$ & $\begin{array}{c}10 \\
(6.71)\end{array}$ \\
\hline Matriculate & 5 & 6.50 & 2 & 2.73 & 17 & 22.97 & 12 & 15.79 & $\begin{array}{c}22 \\
(14.57)\end{array}$ & $\begin{array}{c}14 \\
(9.39)\end{array}$ \\
\hline Hr. Sec & - & - & - & - & 4 & 5.40 & 3 & 3.95 & $\begin{array}{c}4 \\
(2.65)\end{array}$ & $\begin{array}{c}3 \\
(2.01)\end{array}$ \\
\hline Graduates & 1 & 1.30 & - & - & 14 & 18.92 & 5 & 6.58 & $\begin{array}{c}15 \\
(9.93)\end{array}$ & $\begin{array}{c}5 \\
(3.36)\end{array}$ \\
\hline Post graduates & - & - & - & - & 8 & 10.81 & 4 & 5.26 & $\begin{array}{c}8 \\
(5.30)\end{array}$ & $\begin{array}{c}4 \\
(2.68)\end{array}$ \\
\hline $\begin{array}{l}\text { Professional } \\
\text { diploma }\end{array}$ & - & - & - & - & 2 & 2.71 & 1 & 1.32 & $\begin{array}{c}2 \\
(1.32)\end{array}$ & $\begin{array}{c}1 \\
(0.67)\end{array}$ \\
\hline $\begin{array}{l}\text { Professional } \\
\text { degree }\end{array}$ & - & - & 1 & 1.37 & 2 & 2.71 & 3 & 3.95 & $\begin{array}{c}2 \\
(1.32)\end{array}$ & $\begin{array}{c}4 \\
(2.68)\end{array}$ \\
\hline N.A & - & - & 22 & 30.13 & - & - & 25 & 32.88 & - & $\begin{array}{c}47 \\
(31.54)\end{array}$ \\
\hline Total & 77 & & 73 & & 74 & & 76 & & 151 & 149 \\
\hline
\end{tabular}

\section{Distribution of respondents on basis of occupation}

The study was conducted to analyse the occupational pursuits after analyzing the educational qualifications of the respondents and the data is presented in Table 4 . The distribution of the total sample reveals that nearly 53.91 percent of the spouses and 18.38 per cent of the males didn't have any occupation. The larger number of spouses indicates that they fall in the housewife categories. Besides this 31.30 percent of the spouses represent the agriculturalists with 30.27 percent of males. In the rural- urban context the data makes it obvious that a considerable number of spouses 51.15 percent do not have any occupation and a large percentile of 45.45 represents agriculture. The data further indicates that the number of farmers in rural areas is very high. Further, it can be clearly summarized that a higher percentage of traders, teachers, skilled and un-skilled labours are represented by the urban areas. In the categories of housewife the number of urban respondents and spouses is much higher than the rural respondents and spouses.

Table.4: Occupation wise distribution of elderly in urban and rural areas

\begin{tabular}{|c|c|c|c|c|c|c|c|c|c|c|}
\hline \multirow[t]{2}{*}{ Occupation } & \multicolumn{4}{|c|}{ Rural } & \multicolumn{4}{|c|}{ Urban } & \multirow{2}{*}{$\begin{array}{l}\text { Total } \\
\text { self }\end{array}$} & \multirow{2}{*}{$\begin{array}{l}\text { Total } \\
\text { spouse }\end{array}$} \\
\hline & Self & $\%$ age & Spouse & $\%$ age & Self & \%age & Spouse & $\%$ age & & \\
\hline N.A. & 25 & 29.76 & 34 & 51.51 & 9 & 8.91 & 28 & 57.14 & $\begin{array}{c}34 \\
(18.38)\end{array}$ & $\begin{array}{c}62 \\
(53.91)\end{array}$ \\
\hline Semi skilled labour & 4 & 4.76 & - & - & 15 & 14.85 & - & - & $\begin{array}{c}19 \\
(10.27)\end{array}$ & - \\
\hline Skilled & 1 & 1.19 & - & - & 22 & 21.78 & 3 & 6.12 & 23 & 3 \\
\hline
\end{tabular}




\begin{tabular}{|c|c|c|c|c|c|c|c|c|c|c|}
\hline & & & & & & & & & $(12.43)$ & $(2.61)$ \\
\hline Farmer & 48 & 57.14 & 30 & 45.45 & 8 & 7.92 & 6 & 12.24 & $\begin{array}{c}56 \\
(30.27)\end{array}$ & $\begin{array}{c}36 \\
(31.30)\end{array}$ \\
\hline Teacher & 2 & 2.38 & - & - & 21 & 20.79 & 7 & 14.28 & $\begin{array}{c}23 \\
(12.43)\end{array}$ & $\begin{array}{c}7 \\
(6.09)\end{array}$ \\
\hline Traders & - & - & 1 & 1.52 & 19 & 18.81 & 3 & 6.12 & $\begin{array}{c}19 \\
(10.27)\end{array}$ & $\begin{array}{c}4 \\
(3.48)\end{array}$ \\
\hline Merchants & - & - & - & - & - & - & 1 & 2.04 & - & $\begin{array}{c}1 \\
(0.87)\end{array}$ \\
\hline Administration & - & - & - & - & 5 & 4.95 & - & - & $\begin{array}{c}5 \\
(2.70)\end{array}$ & \\
\hline Landlords & 4 & 4.76 & 1 & 1.52 & 2 & 1.98 & 1 & 2.04 & $\begin{array}{c}6 \\
(3.24)\end{array}$ & $\begin{array}{c}2 \\
(1.74)\end{array}$ \\
\hline Total & 84 & & 66 & & 101 & & 49 & & 185 & 115 \\
\hline
\end{tabular}

\section{Income-wise distribution of respondents}

The income-wise distribution of the respondents and the spouses reveals that 13.75 percent and 61.43 percent respectively do not have any income of their own with 69.70 percent of the spouses in urban and 54.05 percent in the rural areas. The data presented in Table 5 indicates that the maximum number of spouse (61.43 percent) are covered under no income group whereas; the maximum males are coved under the income group Rs 2000 to Rs 6000. Further, among rural and urban area a larger group was observed in range of Rs 2000-6000and Rs 6000 to
40,000 respectively. With the increase in income slab, the number of the urban respondents have increased considerably in comparison to those in rural areas. The income distribution thus indicates that in rural and urban areas the male have more income than the spouses and the difference is quite large. The data also indicate that urban aged have relatively higher income than the rural aged people. In the other words, the urban aging population is income wise comfortably placed in relation to the rural aged population.

Table 5. Income wise distribution of elderly in urban and rural areas

\begin{tabular}{|c|c|c|c|c|c|c|c|c|c|c|}
\hline \multirow[t]{2}{*}{ Income (Rs) } & \multicolumn{4}{|c|}{ Rural } & \multicolumn{4}{|c|}{ Urban } & \multirow{2}{*}{$\begin{array}{l}\text { Total } \\
\text { self }\end{array}$} & \multirow{2}{*}{$\begin{array}{l}\text { Total } \\
\text { spouse }\end{array}$} \\
\hline & Self & \%age & Spouse & \%age & Self & \%age & Spouse & \%age & & \\
\hline N.A. & 12 & 15.79 & 40 & 54.05 & 10 & 11.90 & 46 & 69.70 & $\begin{array}{c}22 \\
(13.75)\end{array}$ & $\begin{array}{c}86 \\
(61.43)\end{array}$ \\
\hline $2000-6000$ & 52 & 68.42 & 30 & 40.55 & 24 & 28.57 & 7 & 10.61 & $\begin{array}{c}76 \\
(47.50)\end{array}$ & $\begin{array}{c}37 \\
(26.43)\end{array}$ \\
\hline $6001-15000$ & 10 & 13.16 & 3 & 4.05 & 34 & 40.48 & 10 & 15.15 & $\begin{array}{c}44 \\
(27.50)\end{array}$ & $\begin{array}{c}13 \\
(9.29) \\
\end{array}$ \\
\hline $\begin{array}{l}15001-40000 \& \\
\text { above }\end{array}$ & 2 & 2.63 & 1 & 1.35 & 16 & 19.05 & 3 & 4.54 & $\begin{array}{c}18 \\
(11.25)\end{array}$ & $\begin{array}{c}04 \\
(2.86)\end{array}$ \\
\hline Total & 76 & & 74 & & 84 & & 66 & & 160 & 140 \\
\hline
\end{tabular}

\section{Source of income}

During the study, the respondents were asked about the sources of income and about 4.33 per cent in the total sample have no source of income with 0.66 percent rural and 8 percent urban respondents (Table 6). The majority of the respondents (39.33 percent) with maximum value of 64 percent in rural and 14.66 percent in urban receives their income from agriculture followed by 24.26 percent income from pension. About 17.66 per cent of the total receives remittances from sons with maximum in rural areas. The rural-urban comparison indicates that while rural based senior citizens in maximum number get income from remittances and agriculture, the majority of urban based senior citizens receive income from pensionsfollowed by those having agriculture income, remittances and business returns. The rental income and investments returns are found only in the case of urban senior citizens. The data thus indicates that the urban based senior citizens have more income sources in comparison to their counterparts in the rural areas.

Table 6. Source of income of elderly in urban and rural areas 


\begin{tabular}{|l|c|c|c|c|c|c|}
\hline Source & Rural & Percentage & Urban & Percentage & Total & Percentage \\
\hline No source & 1 & 0.66 & 12 & 8.00 & 13 & 4.33 \\
\hline Remittance from daughter & 2 & 1.33 & - & - & 2 & 0.66 \\
\hline Remittance from Sons & 31 & 20.26 & 22 & 14.66 & 53 & 17.66 \\
\hline Old age pension & 13 & 8.66 & 3 & 2.00 & 16 & 5.33 \\
\hline Rental income & - & - & 7 & 4.66 & 7 & 2.33 \\
\hline Investment & - & - & 5 & 3.33 & 5 & 1.66 \\
\hline Service Pension & 7 & 4.66 & 67 & 44.66 & 74 & 24.26 \\
\hline Agriculture income & 69 & 64.00 & 22 & 14.66 & 118 & 39.33 \\
\hline Business & - & - & 12 & 8.00 & 12 & 4.00 \\
\hline Total & 150 & & 150 & & 300 & \\
\hline
\end{tabular}

\section{Living arrangements}

In the traditional society, the aged depended on the other members of the family, the caste group and community at large. However, much has undergone change particularly with the change of family form from joint to nuclear. Himachal Pradesh has however continued to be more family oriented society with strong family ties. This is evident from the data presented in Table 7 as most of the aged are found living in their own homes in rural and urban areas. The difference is marginal between the rural and urban-based aged. However, it is further observed that while almost one third in the rural areas depends on their sons, a similar number in urban areas live in the rented accommodation. The remaining small number is found living with theirdaughters and sons. The data thus reveal that urban based aged living in rented accommodation do not have the same living arrangement support base as the rural based respondents.

Table 7. Living arrangements of rural and urban aged population

\begin{tabular}{|c|c|c|c|c|c|c|}
\hline & Rural & Percentage & Urban & Percentage & Total & Percentage \\
\hline \multicolumn{7}{|l|}{ Living arrangement } \\
\hline Own house & 94 & 62.66 & 96 & 64.00 & 190 & 63.33 \\
\hline Son & 47 & 31.33 & 5 & 3.33 & 52 & 17.33 \\
\hline Rental & 1 & 0.66 & 46 & 30.66 & 47 & 15.66 \\
\hline Daughter & 4 & 2.66 & 2 & 1.33 & 6 & 2.00 \\
\hline Other shelter & 4 & 2.66 & 1 & 0.66 & 5 & 1.66 \\
\hline Total & 150 & & 150 & & 300 & \\
\hline \multicolumn{7}{|l|}{ Living accommodation } \\
\hline Separate room & 120 & 80.00 & 85 & 56.67 & 205 & 68.33 \\
\hline Sharing with grand children & 16 & 10.66 & 57 & 38.00 & 73 & 24.33 \\
\hline Sharing with adults & 14 & 9.33 & 8 & 5.33 & 22 & 7.33 \\
\hline Total & 150 & & 150 & & 300 & \\
\hline
\end{tabular}

The study further indicates that the majority of old people (80.00 percent) have separate room for their living in rural as compared to 56.67 percent in urban areas. Some of the elderly people in rural areas are found sharing their living room while about 38 percent of urban aged population shares room with their grand-children. The number of elderly living with their adult relatives is quite small (5.33 to 9.33 percent). Thus the data indicate that the majority of elderly people like to live in separate room. The reason perhaps is that the elderly people have a routine of life which is considerably different from others in the active age group oryounger family members.

Cash reserves of the aged in rural and urban areas
Further analysis of cash assets of the respondents reveals that of the total 47.33 percent do not have any cash assets and this figure is constituted by 56.66 per cent of the rural respondents and 38 percentage of the urban respondents (Table 8). The majority (29.33 percent) among those who own cash up to Rs. 40,000 live in the rural areas with only 3.33 percent in the urban areas. The number of senior citizens owning between Rs. 41,000-80,000 is almost similar in rural as well as urban areas. However, comparatively a larger number of people is having cash assets between Rs, 80,000 to 1 Lakh living in the urban areas 54 percent in comparison to only 8 per cent in the rural areas. 
Table 8. Cash reserves of the aged in rural and urban areas

\begin{tabular}{|l|l|l|l|l|l|l|}
\hline Cash (Rs) & Rural & Percentage & Urban & Percentage & Total & Percentage \\
\hline N.A. & 85 & 56.66 & 57 & 38.00 & 142 & 47.33 \\
\hline Upto 40,000 & 44 & 29.33 & 5 & 3.33 & 49 & 16.33 \\
\hline $41,000-80000$ & 9 & 6.00 & 7 & 4.66 & 16 & 5.33 \\
\hline $81,000-1,00,000$ above & 12 & 8.00 & 81 & 54.00 & 93 & 31.00 \\
\hline Total & 150 & & 150 & & 300 & \\
\hline
\end{tabular}

The on-going developments in the field of health sciences, family welfare and reproductive technologies, social and economic infrastructure during the last few decades have resulted in increase in the life expectancy at birth, decline in fertility and mortality rates in the developed as well as the developing countries. This in turn has led to the increase in the percentage of ageing population all over the world. The Director General of Help age India, draws attention towards what is going to be the scenario with the number of the aged having increased from 17 million in 1951 to 70 million in 1990's. Also what would be the fate of the millions of such people as their number is further expected to rise to 177 million by next 25 years. The family and housing related issues such as the effect of ageing on housing conditions for the elderly and the State policy and programmes to promote family care for the aged become too complicated over the years (United Nations, 1994).

The present study revealed that majority of senior citizens belonged to the age group 60-70 years both in rural $(67.33 \%)$ and urban $(76 \%)$ areas. A study on senior citizens in rural areas showed that $66 \%$ of study subjects belonged to the age group of 65-75 years (Usha and Lalitha $2011 \mathrm{a}, \mathrm{b})$. Similar findings were also reported by Indu et al. (2007). Majority (56 to $73 \%$ ) of senior citizens in rural areas are illiterate and having only primary education, whereas $16-23 \%$ of elders in urban areas had a secondary level of education. This finding is in consistent with previous studies reported by Usha and Lalitha (2011 a, b). Majority of senior citizens in urban areas had regular income, whereas in rural areas the income is mainly from agriculture. This finding was supported by Indu et al. (2007) and Usha et al. (2009).

\section{CONCLUSION}

In this way the data indicates that the majority of the rural based seniorcitizens have less economic assets than those in the urban areas. In view of the above discussion on the personal income, occupation, the movable assets, and living arrangements it is found that the urban based senior citizens are batter placed than their rural counter parts. The overall socio-economic status of population in the village is not good. About 61.43 percent spouse and 13.75 percent men in total don't have any income source. The maximum number of respondents in villages is covered under the income group of Rs 2000 to 6000 in Shimla district of Himachal Pradesh. The lower income groups of people mainly engaged in agricultural fields, or unskilled labour. Although comparatively higher income population enjoy a little better life but lower income population's socioeconomic situation is very risky due to mainly low level of literacy and low income resulting create many social issues and problems.

\section{REFERENCES}

[1] Bollen, A.K., Glanville, L.J., and Stecklov G. 2001. SocioEconomic Status and Class in Studies of Fertility and Health in Developing Countries, Annu Rev Sociol, 27:153185.

[2] Celich SLK, Creutzberg M, Goldim JR, Gomes. 2010. Ageing with quality of life: the perception of elderly participants in groups of senior citizens. REME RevMinEnferm. 14(2):226-32.

[3] Census of India.(2011). Single year age data-C13 Table (India/ States/UTs). http://www.censusindia.gov. in/2011census/population_enumeration.html

[4] Census.2011. Population Composition (2011) Vol. 2014 Government of India, New Delhi.

[5] Indu PV, Subha N, Ramachandran A. 2007. An experience from psycho-geriatric clinic of a tertiary care centre. Kerala J Psychiatry. 22:15-22.

[6] Krieger, N., Williams, DR., Moss, HW. 1997. Measuring Social Class in US Public Health Research: concepts, methodologies and guidelines. Annul Rev Public Health. 18: 341-78.

[7] Lesourd B. 2004. Nutrition: A major factor influencing immunity in the elderly. J Nutr Health Aging. 8:28-37.

[8] Lynch J, Kaplan G. 2000.Socio-Economic Position.In: L. F. Berkman and I. Kawachi (Eds.), Social Epidemiology, New York: Oxford University Press, pp. 13-35.

[9] MOSPI. 2016. Elderly in India-profile and programmes. Ministry of statistics and programme implementation. Central Statistics Office. Govt of India, p27.

[10] Mustaquim M, Islam M. 2014. Demographic and SocioEconomic Characteristics of Inhabitants of Udaypur Village, West Bengal, Indian Streams Res J. 4(1): 1-13. 
[11] Rathod G R, Ningshen A.2012.Measuring the SocioEconomic Status of Urban below Poverty Line Families in Imphal City, Manipur: A Livelihoods Study.International JMarketing, Financial Services \& Management Res. 1(12): 62-69.

[12] United Nation.1994. "Report and Recommendations of the Conference", Ageing and the family. New York, pp. 3-5.

[13] UNPD. 2011. United Nations Population Division, World Population Prospects. The 2010 Revision. New York: United Nations, accessed at http://esa.un.org/unpd/wpp.

[14] Usha VK, Lalitha K. 2011a. Physical problems of senior citizens: A gender perspective. Kerala Nurs Forum. 6: 5-15.

[15] Usha VK, Lalitha K. 2011b. Social problems of senior citizens. Nightingale Nurs Times. 7:12-15.

[16] Usha VK, Lalitha K, Padmavathi D. 2009. Depression and cognitive impairment among old age people. Nightingale Nurs Times.5:21-23.

[17] WHO. 1995. The World Health Organization Quality Of Life Assessment (WHOQOL): position paper from the world health organization. SocSci Med. 1995; 41(10):14039.

[18] WHO. 2017. The World Health Organization Nutrition for older persons. www.who.int/nutrition/topics/ageing/en/index1.html.

[19] World Population Ageing. 2015.Ageing Highlights (2015). Department of Economic and Social Affairs, United Nations, New York 